\title{
Antihypertensive treatment in people with dementia
}

Veronika van der Wardt, Pip Logan, Simon Conroy, Rowan Harwood, John Gladman

\section{Abstract}

\section{Introduction}

The range and magnitude of potential benefits and harms of antihypertensive treatment in people with dementia has not been previously established.

\section{Method}

A scoping review to identify potential domains of benefits and harms of antihypertensive therapy in people with dementia was undertaken. Systematic reviews of these domains were undertaken to examine the magnitude of the benefits or harms.

\section{Results}

Potential outcome domains identified in the 155 papers in the scoping review were cardio-vascular events, falls, fractures and syncope, depression, orthostatic hypotension, behavioural disturbances, polypharmacy risks, kidney problems, sleep problems, interactions with cholinesterase inhibitors and pain. The systematic reviews across these domains identified relatively few studies done in people with dementia, and no convincing evidence of safety, benefit or harm across any of them.

\section{Discussion}

There is no justification for materially different guidance for the treatment of hypertension in people with dementia, but sufficient evidence to warrant particular caution and further research into treatment in this group of patients.

\section{Introduction}

The WHO 2012 report "Dementia: a public health priority" estimated that there are 35.6 million people with dementia living at present worldwide ${ }^{1}$. About half of people over 50 years of age have hypertension ${ }^{2}$. While the protective effects of antihypertensive treatment against cardiovascular events have been established in numerous clinical trials for different age groups ${ }^{3-4}$ including the very $\mathrm{old}^{5}$, people with dementia have been consistently excluded from these studies. The favourable benefit to risk ratio seen in studies of hypertension treatment in fit older people might not apply if 
people with dementia are at a higher risk from the side effects of anti-hypertensive treatment than people with normal cognition (for example through falls or other adverse drug effects), and if they are less likely to be recognised or reported than in those with normal cognition. Therefore management of hypertension in people with dementia may need to be different from in those with normal cognition ${ }^{6}$. However, current guidelines for the treatment of hypertension do not provide specific advice for people with dementia.

There have been no reviews to comprehensively examine studies investigating the range of outcomes (including harmful effects) of antihypertensive treatment in people with dementia. Such work is important to clarify whether there is a case for altered guidance for the management of hypertension in people with dementia.

\section{Methods}

A two stage process was undertaken. In the first stage, a scoping review ${ }^{7}$ was undertaken to identify the range of outcomes of antihypertensive treatment in people with dementia. In the second stage, systematic reviews were undertaken for each of the main areas of harmful or adverse outcomes identified in the first stage.

\section{Stage 1: scoping review}

\section{Protocol}

The scoping review was based on a pre-defined protocol to search and identify relevant research articles.

\section{Eligibility}

Inclusion: All articles reporting original research regarding the treatment of hypertension in people with dementia were included. No publication date limit was applied Exclusion: All studies investigating hypertension as a risk factor for dementia; effects on carers; specific non-dementia diseases (e.g. cancer) and rarer forms of dementia (Korsakoff's syndrome, dementia due to HIV, normal pressure hydrocephalus, CADASIL); animal studies and non-English 
language articles. As effects of antihypertensive drugs on the progression of dementia have been reviewed elsewhere ${ }^{8-9}$, they were excluded from the literature analysis.

Information sources

Pubmed, Embase, Web of Science and the Cochrane library databases were searched.

\section{Search}

The search for articles took place from July 2012 and was updated in February 2013. Searches were limited to English language human research articles. Search terms included combinations of 'hypertension', 'antihypertensive drug', 'antihypertensive treatment' or 'blood pressure' in combination with 'dementia' or 'Alzheimer's disease'

\section{Selection}

Duplicates were removed, titles and abstracts were examined by one person $(\mathrm{Vv} / \mathrm{dW})$ and inclusion and exclusion criteria applied. Full text versions of the remaining papers were obtained and assessed again based on inclusion and exclusion criteria. The remaining relevant articles were used to identify the range of outcomes examined in scientific articles.

Data collection

Main outcome variables were recorded and categorized into topics.

Analysis

The number of papers examining each outcome was tabulated.

\section{Stage 2 systematic reviews}

\section{Protocol}

The systematic reviews were based on a pre-defined protocol to search and identify relevant research papers. 
Eligibility

Inclusion: All articles reporting original research regarding antihypertensive treatment in people with dementia and the topic identified in stage 1 were included. No publication date limit was applied.

Exclusion: As in stage 1. Studies which did not include antihypertensive treatment in any form in the analysis (as composite variable or individual medication classes) were also excluded.

\section{Information sources}

Pubmed, Embase, Web of Science and the Cochrane library databases were searched.

Search

Articles were searched until June 2013 publication dates. Searches were limited to English language and, where possible, human research articles. Search terms for stage 2 included 'antihypertensive' or antihypertensive drug classes ('diuretics', 'beta blockers', 'calcium channel blockers', 'angiotensin receptor blockers' and 'ACE inhibitors') in combination with 'dementia' or 'Alzheimer's disease' and the topics identified in stage 1 (see flow diagram 1).

\section{Selection}

Duplicates were removed, titles and abstracts were examined by one person (VvdW) and inclusion and exclusion criteria applied. Full text versions of the remaining papers were obtained and assessed based on inclusion and exclusion criteria. The remaining relevant articles were included and the number of papers examining each topic was recorded.

\section{Data collection}

Methods and results were extracted to record purpose of the study, design, sample size, main measurements and results of each study.

Analysis

Method sections of papers were examined to determine level of evidence. Results were compared and analysed regarding the effect of antihypertensive treatment on the topic in question. 


\section{Results}

Stage 1 - Scoping review

Figure 1 shows that 155 papers entered this review.

Figure 1 Scoping review

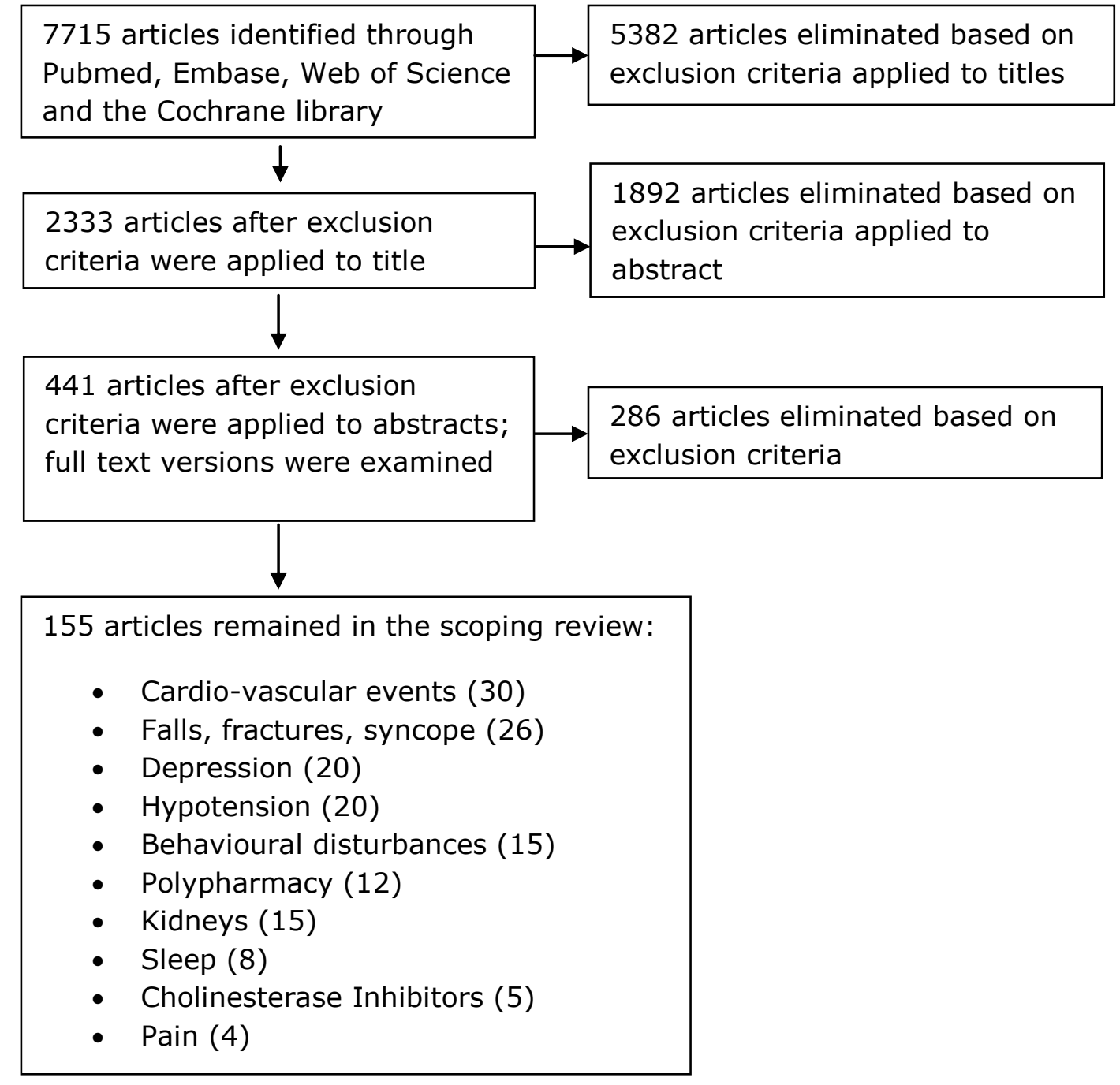

Ten main outcome themes of effects of antihypertensive treatment in people with dementia emerged from the 155 papers in the scoping review (flow diagram 1); cardio-vascular events, falls, fractures and syncope, depression, hypotension, behavioural disturbances, polypharmacy, kidney problems, sleep problems, cholinesterase inhibitors and pain. The articles identified in the last stage of the scoping review were also included into the stage 2 analysis. 
Table 1 shows a summary of the findings of the searches undertaken in the systematic reviews of the topics identified in the scoping review.

Table 1 Search terms 'dementia' or 'Alzheimer's' in combination with antihypertensive, diuretics, beta blockers, calcium channel blockers, angiotensin receptor blockers or ACE inhibitors

\begin{tabular}{|l|c|c|}
\hline Search terms & $\begin{array}{l}\text { No. of articles } \\
\text { for which full } \\
\text { texts were } \\
\text { obtained }\end{array}$ & $\begin{array}{l}\text { No. of articles } \\
\text { investigating effects of } \\
\text { antihypertensive } \\
\text { treatment in people } \\
\text { with dementia }\end{array}$ \\
\hline Stroke, cardiovascular & 107 & 5 \\
\hline Falls, fractures, syncope & 58 & 4 \\
\hline Behavioural problems, & 13 & 2 \\
\hline aggression, agitation, apathy & 18 & 2 \\
\hline Depression & 39 & 2 \\
\hline Sleep, insomnia, pain, & & \\
\hline kidney, renal problems, & 15 & 0 \\
incontinence & & 23 \\
\hline Eyes, retinal, glaucoma & & \\
\hline Cholinesterase inhibitors & 15 & 2 \\
\hline Polypharmacy & & \\
\hline Hypotension & & \\
\hline
\end{tabular}

\section{$1 \quad$ Cardio- and cerebrovascular events}

In total, four studies examined the effects of antihypertensive medication on cardio- and cerebrovascular events in people with dementia (see table 2), with antihypertensives either as main independent variable (three studies) or as control variable (one study).

No randomized controlled placebo trials have been conducted in this area. In people with dementia, two randomized controlled trials investigated the effects of calcium channel blockers (CCBs) in an intention-to-treat, a efficacy and a safety analysis ${ }^{10-12}$. For both trials, main outcome was cognition but 
the safety analysis included cardio- and cerebrovascular events, which were reported as adverse events. The studies compared a control group against a treatment group using CCBs. Both groups were allowed to continue with unspecified antihypertensive treatment as prescribed before the beginning of the study except alpha methyldopa. The results showed that the control group had significantly more adverse (cerebrovascular) events than the treatment group ${ }^{11-12}$. For cardiovascular events the trend was similar but reached significance in only one of the studies ${ }^{12}$. In a subgroup analysis of participants with sub-cortical vascular dementia ${ }^{13}$, no significant differences in these adverse events were found, although again the same trend was observed (fewer events in the treatment group). One study was a non-randomized six weeks open label trial including people with dementia into the safety of Nivladipine (CCB) ${ }^{14}$. There was no significant difference in adverse events, but this was a very short period of follow up.

In addition, a prognostic cohort study including a large group of people diagnosed with dementia investigated the effects of angiotensin receptor blockers and ACE inhibitors on the risk of hospitalization and mortality while controlling for cerebro-and cardiovascular events ${ }^{10}$. The results showed that while there was no significant association between angiotensin receptor blockers and risk for hospitalisation or mortality, ACE inhibitors significantly increased the risk for mortality but not for hospitalisation. This association remained significant after controlling for coronary heart disease, stroke and congestive heart failure.

\section{Falls, fractures and syncope}

The risk of falls and fractures is higher in people with dementia compared to those without ${ }^{15-17}$. In addition, some antihypertensive treatments have been shown to increase the risk for falls and fractures in older people ${ }^{18-19}$. However, this review found no evidence from randomized controlled trials for the risk of falls due to antihypertensive medication in people with dementia. This review identified four prospective cohort studies, two of those investigating the association between falls risk and antihypertensive medication in people with dementia ${ }^{20-22}$, and a further two examining the association of falls risk with cardiovascular medication ${ }^{23-24}$ (Table 2). Cardiovascular medication included antihypertensive drugs as well as anticoagulants and antiplatelet agents. 
The findings showed conflicting results in people with dementia. Examining risk factors for falls in people with and without dementia, Eriksson et al. ${ }^{20-21}$ found that taking diuretics was a significant risk factor for falls for people with dementia in a univariate analysis, but this was non-significant when controlled for significant covariates, but taking more than four drugs was a significant risk factor for falling in people with dementia after controlling for significant covariates. Pellfolk et al. ${ }^{22}$ found no significant difference in the use of antihypertensive medication between fallers and non-fallers in people with dementia and therefore did not enter antihypertensive medication in their logistic regression analysis of independent risk factors of falls. However, Allan et al. ${ }^{23}$ reported that cardiovascular medication was a significant predictor of falls in an analysis of all types of dementia combined (Alzheimer's disease, vascular dementia, dementia with Lewy bodies and Parkinson's with dementia), as well as when stratified per dementia type. When significant and potentially modifiable predictors were entered into a multivariate analysis, which was stratified by dementia type, cardiovascular medication remained significantly associated with falls. Asada et al. ${ }^{24}$, on the other hand, found that cardiovascular medication was not a significant contributor to falls-related injuries in people with dementia.

\section{Behavioural problems}

Only the effects of beta (Propranolol/Pindolol) and alpha blockers (Prazosin) on behavioural symptoms in people with dementia have been investigated in randomised controlled trials (Table 2). All three trials had very small sample sizes (between 6 and 31 participants) but showed a significant beneficial effect of centrally active antihypertensive medication on behavioural problems. Herrmann et al. ${ }^{25}$ showed that verbal aggression was significantly reduced in people using beta-blockers, without a significant change in total aggression. Peskind, Tsuang and Bonner ${ }^{26}$ found no significant association between use of beta blockers and any specific behavioural subscale but a significant effect of beta blocker use on the total behavioural score. A small randomised controlled trial to assess the effect of alpha blockers on behaviour showed that non-significantly greater improvements in the treatment group than in the control group ${ }^{27}$. A case series study to assess the effect of beta blockers on behaviour in people with dementia ${ }^{28}$ indicated significant improvements for all behavioural measures (except for wandering, which improved on only one scale). Behavioural improvements after using beta blockers were also found in another case study including people with dementia ${ }^{29}$. Meta-analyses 
showed that beta blockers have relatively little effect on cerebro- and cardiovascular events and mortality compared to other antihypertensive drugs ${ }^{30-31}$, and are more likely to be discontinued ${ }^{32}$. Other antihypertensive treatments have not been investigated for their effect on behavioural problems.

\section{Depression}

Antihypertensive treatment, in particular the use of highly lipid-soluble beta blockers, has been associated with depression ${ }^{33}$. One randomised controlled trial and one cohort study investigated the relationship between antihypertensive treatment and depression in people with dementia. The randomised controlled trial investigated the effect of Nimodipine (CCB) on depression in patients with diagnosed dementia as well as those with mild to moderate cognitive decline on the Global Deterioration scale ${ }^{34}$. The treatment and control group were allowed to use other medication including antihypertensive treatment. Scores on the Hospital Anxiety and Depression scale improved significantly more in the treatment group than in the control group. In a large cohort study examining the prevalence of depression in people with dementia, Newman ${ }^{35}$ found that beta blocker use was not a significant covariate in the relationship between dementia and diagnosis of major depression. No other antihypertensive drugs were included in the analysis.

\section{Sleep problems, pain, kidney problems and incontinence}

Although these topics emerged during the first stage of this review, there were only a very few studies investigating the effect of antihypertensive medication in people with dementia (Table 2).

Sleep problems are common in people with dementia ${ }^{36-37}$, and sleep disturbances, in particular obstructive sleep apnoea, have been shown to improve with antihypertensive treatment ${ }^{38}$. While there are no studies examining the effects of antihypertensive treatment on sleep quality, one prospective cohort study investigated the relationship between sleep disturbances and nocturnal reduction of blood pressure in people with dementia whilst controlling for antihypertensive treatment ${ }^{39}$. The results showed no significant difference in use of antihypertensive medication between dippers (hypertensive patients who experience a nocturnal reduction in blood pressure) and non-dippers (those who do not). Other sleep disturbances have not been investigated in people with dementia in relation to use of antihypertensive medication. 
Some antihypertensive drugs such as beta blockers, angiotensin receptor blockers and ACE inhibitors seem to have beneficial effects on pain in older people without dementia ${ }^{40-41}$. For people with dementia, however, the association between pain and antihypertensive treatment has not yet been investigated.

The relationship between kidney problems and antihypertensive medication has not been assessed in people with dementia. One cohort study including geriatric emergency patients investigated the association. The results showed that antihypertensive drugs may contribute to an increased risk of a clinically relevant impairment of renal function ${ }^{42}$. However, although $56 \%$ of the participants were diagnosed with dementia and no separate analysis for this group was conducted.

The effect of antihypertensive drugs on incontinence has been examined by Ruby et al. ${ }^{43}$ in a large cohort study of older people. They reported that use of alpha blockers was significantly associated with urinary incontinence. Ridgeway et al. ${ }^{44}$ investigated the relationship between incontinence and use of antihypertensive medication in a long-term care population with $79 \%$ being diagnosed with dementia. The results indicated that while dementia was significantly associated with urinary and faecal incontinence, antihypertensive medication was not individually related to incontinence. However, a sub-analysis including only people with dementia was not reported.

\section{Use of Cholinesterase inhibitors}

Cholinesterase inhibitors are commonly used in the mild to moderate stages of Alzheimer's disease. Several studies investigated the interaction effects between cholinesterase inhibitors and antihypertensive medication (Table 2) although the evidence is limited to cohort studies and population database studies, no randomised controlled trials have been conducted to assess these effects.

The results of a prospective cohort study ${ }^{45}$ showed significant better cognition in those taking antihypertensive drugs compared to those not taking them. Other studies, however, demonstrated that the joint use of antihypertensive medication and cholinesterase inhibitors was associated with a significantly increased risk of serious adverse drug reactions. Grossberg et al. ${ }^{46}$ found no significant interaction between rivastigmine and antihypertensive medication as a group in their cohort study but when analysed separately, the use of diuretics and rivastigmine was related to a significantly higher rate of serious adverse events while centrally acting antihypertensives, ACE inhibitors and calcium 
channel blockers were not. Furthermore, the results of two database studies showed that use of antihypertensive treatment was significantly associated with serious adverse drug reactions in patients treated with cholinesterase inhibitors ${ }^{47}$ and beta blockers were among the most frequently encountered drugs involved in drug-drug interactions with cholinesterase inhibitors ${ }^{48}$.

These studies indicate that the combination of cholinesterase inhibitors and antihypertensive medication might result in benefits (improvement of cognition) as well as harms (serious adverse drug reactions), which might depend on drug class.

\section{Polypharmacy and inappropriate medications}

All antihypertensive medications contribute to polypharmacy and its harmful effects ${ }^{49}$, but only two cohort studies investigated antihypertensive drug use in the context of polypharmacy in people with dementia (Table 2). A longitudinal cohort study compared drug use between people with and without dementia $^{50}$, showing that people with dementia used significantly more loop diuretics than people without dementia, and significantly less beta blockers and calcium channel blockers. Inappropriate antihypertensive drug use (estimated daily dose in excess of assumed average maintenance dose per day of a drug used for its main indication in an adult) did not differ between people with and without dementia. Montastruc et al. ${ }^{51}$ investigated the use of potentially inappropriate medication in people with dementia in a cohort study, showing that $3.1 \%$ of people with mild to moderate Alzheimer's disease used inappropriate centrally acting antihypertensive medication and $2.9 \%$ used inappropriate short-acting calcium-channel inhibitors.

\section{Orthostatic hypotension}

Orthostatic hypotension is associated with poorer cognition ${ }^{52-53}$ and occurs significantly more often in people with dementia than without ${ }^{54}$. However, the role of antihypertensive medication in this context is unclear. Again, no randomised controlled trials have been conducted to examine the relationship between antihypertensive treatment and hypotension in people with dementia. The non-randomised open label trial, which looked at safety of Nivladipine for people with dementia ${ }^{14}$, found no significant difference between treatment and control group in the incidence of orthostatic hypotension.

In a cross-sectional cohort study, Anderson et al. ${ }^{54}$ found that differences in incidence of orthostatic hypotension between people with Alzheimer's disease, Lewy Body dementia and without dementia 
were independent of the use of antihypertensive treatment. Mehrabian et al. ${ }^{55}$ confirmed these results in a cohort study including people with memory complaints including dementia when looking at use or no use of antihypertensive treatment (Table 2). While worse cognitive function and number of different antihypertensives were significantly associated with orthostatic hypotension, it was not reported if the number of different antihypertensive drugs was significantly related to orthostatic hypotension for the dementia group separately. 
Table 2 Articles included in the analysis

\begin{tabular}{|c|c|c|c|c|c|c|}
\hline Area & $\begin{array}{l}\text { Author \& } \\
\text { year }\end{array}$ & Research question & Design & Sample size & Main measurements & Results \\
\hline \multirow[t]{5}{*}{$\begin{array}{l}\text { Cardio- and } \\
\text { cerebro- } \\
\text { vascular } \\
\text { events }\end{array}$} & $\begin{array}{l}\text { Kehoe, } \\
\text { Davies \& } \\
\text { Martin } \\
(2013) \\
{[10]}\end{array}$ & $\begin{array}{l}\text { How do ACE-Is and } \\
\text { ARBs affect the } \\
\text { risk for } \\
\text { hospitalization and } \\
\text { mortality in people } \\
\text { with dementia? }\end{array}$ & $\begin{array}{l}\text { Prognostic } \\
\text { cohort study } \\
\text { based on } \\
\text { primary care } \\
\text { database }\end{array}$ & $\begin{array}{l}\mathrm{N}=6290 \text { (all with } \\
\text { dementia diagnosis and } \\
\text { using } \mathrm{AHT} \text { ) }\end{array}$ & $\begin{array}{l}\text { Health } \\
\text { Death } \\
\text { Hospitalisation }\end{array}$ & $\begin{array}{l}\text { ACE-Is: sig associated with } \\
\text { mortality in patients with AD (HR } \\
1.19 ; \text { CI* } 1.07-1.33) \text { and } \\
\text { combined dementia group (HR } \\
1.20 ; \text { CI } 1.10-1.30) \text { after } \\
\text { adjustments but no association } \\
\text { with hospitalization; } \\
\text { ARBs: no significant associations }\end{array}$ \\
\hline & $\begin{array}{l}\text { Kennelly, \& } \\
\text { al. (2011) } \\
{[14]}\end{array}$ & $\begin{array}{l}\text { Is nivladipine save } \\
\text { and tolerable for } \\
\text { people with AD? }\end{array}$ & $\begin{array}{l}\text { Non- } \\
\text { randomized } \\
\text { open label } \\
\text { trial ( } 6 \mathrm{wks} \text { ) }\end{array}$ & $\begin{array}{l}\text { Treatment group } n=56 \\
\text { control group } n=30 \text { all } \\
\text { used other AHTs as well }\end{array}$ & $\begin{array}{l}\text { Inappropriate } \\
\text { reduction in BP } \\
\text { AEs } \\
\text { Falls (self report) } \\
\text { Orthostatic } \\
\text { symptoms }\end{array}$ & $\begin{array}{l}\text { No sig. effect on BP after } \\
\text { adjustments; no change in } \mathrm{OH} \text { in } \\
\text { either group; no significant } \\
\text { difference in reported AEs between } \\
\text { groups but more AEs in treatment } \\
\text { group } 39.0 \% \text { vs } 23.3 \text { in control } \\
\text { group). }\end{array}$ \\
\hline & $\begin{array}{l}\text { Pantoni, } \\
\text { Bianchi, \& } \\
\text { al. (2000) } \\
{[11]}\end{array}$ & $\begin{array}{l}\text { Is nimodipine } \\
\text { efficient in } \\
\text { improving } \\
\text { cognition and } \\
\text { slowing } \\
\text { deterioration as } \\
\text { well as save for } \\
\text { people with multi- } \\
\text { infarct dementia? }\end{array}$ & $\begin{array}{l}\text { Double blind } \\
\text { RCT intention } \\
\text {-to-treat (itt), } \\
\text { safety and } \\
\text { efficacy } \\
\text { analyses }\end{array}$ & $\begin{array}{l}\text { Treatment } n=128 ; \\
\text { control } n=131 ; \text { safety } \\
\text { analysis } n=259 ; \\
\text { itt } n=251 \text {, efficacy } \\
n=209 \text {, all multi-infarct } \\
\text { dementia, controls used } \\
\text { other AHTs }\end{array}$ & $\begin{array}{l}\text { Functional rating } \\
\text { scale } \\
\text { ADL } \\
\text { Rapid Disability } \\
\text { Scale, CDR } \\
\text { Clinical Global } \\
\text { Impression } \\
\text { Cognition } \\
\text { AEs and SAEs }\end{array}$ & $\begin{array}{l}\text { AEs and SAEs analysis showed } \\
\text { that only cerebro-vascular events } \\
\text { were sig. more in placebo group } \\
\text { (AE: } 6 \text { in treatment vs } 17 \text { in } \\
\text { placebo group; SAE: } 16 \text { in } \\
\text { treatment vs } 22 \text { in placebo group, } \\
\text { Other results concerning cognition } \\
\text { or functioning are all non } \\
\text { significant. }\end{array}$ \\
\hline & $\begin{array}{l}\text { Pantoni, } \\
\text { Rossi \& al. } \\
(2000) \\
{[13]}\end{array}$ & $\begin{array}{l}\text { Is nimodipine } \\
\text { efficient in } \\
\text { improving } \\
\text { cognition and } \\
\text { slowing } \\
\text { deterioration as } \\
\text { well as save for } \\
\text { people with } \\
\text { subcortical } \\
\text { vascular dementia? }\end{array}$ & $\begin{array}{l}\text { Sub analysis } \\
\text { of double blind } \\
\text { RCT; intention } \\
\text {-to-treat (itt), } \\
\text { safety and } \\
\text { efficacy } \\
\text { analyses }\end{array}$ & $\begin{array}{l}\text { Treatment } n=45 ; \text { control } \\
n=47 ; \text { safety analysis } \\
n=92 ; \\
\text { itt } n=87 \text {, efficacy } n=77 \text {, } \\
\text { all subcortical VaD, } \\
\text { controls use other AHTs }\end{array}$ & $\begin{array}{l}\text { Functional rating } \\
\text { scale } \\
\text { ADL } \\
\text { Rapid Disability } \\
\text { Scale, CDR } \\
\text { Clinical Global } \\
\text { Impression } \\
\text { cognition } \\
\text { AEs and SAEs }\end{array}$ & $\begin{array}{l}\text { Due to low numbers, no statistical } \\
\text { significance could be established } \\
\text { but more controls than people in } \\
\text { treatment group had SAEs and } \\
\text { total AEs. More people in } \\
\text { treatment group had BP values } \\
\text { indicating hypotension }\end{array}$ \\
\hline & $\begin{array}{l}\text { Pantoni, \& } \\
\text { al. (2005) }\end{array}$ & $\begin{array}{l}\text { Is nimodipine } \\
\text { efficient in }\end{array}$ & $\begin{array}{l}\text { Double blind } \\
\text { RCT intention }\end{array}$ & $\begin{array}{l}\text { Treatment } \mathrm{n}=124 \\
\text { (baseline) } / 94 \text { (endpoint); }\end{array}$ & $\begin{array}{l}\text { Sandoz Clinical } \\
\text { Assessment Geriatric }\end{array}$ & $\begin{array}{l}\text { Cognitive decline in some aspects } \\
\text { less in treatment group; AEs and }\end{array}$ \\
\hline
\end{tabular}




\begin{tabular}{|c|c|c|c|c|c|c|}
\hline & [12] & $\begin{array}{l}\text { improving } \\
\text { cognition and } \\
\text { slowing } \\
\text { deterioration as } \\
\text { well as save for } \\
\text { people with } \\
\text { subcortical } \\
\text { vascular dementia? }\end{array}$ & $\begin{array}{l}\text {-to-treat (itt), } \\
\text { safety and } \\
\text { efficacy } \\
\text { analyses }\end{array}$ & $\begin{array}{l}\text { control } n=118 \\
\text { (baseline)/55 (endpoint); } \\
\text { safety analysis } n=239 ; \\
\text { itt } n=230 \text {, efficacy } \\
n=149, \text { all subcortical } \\
\text { VaD, controls use other } \\
\text { AHTs }\end{array}$ & $\begin{array}{l}\text { Scale } \\
\text { Global Deterioration } \\
\text { Score } \\
\text { Gait performance } \\
\text { test } \\
\text { Nurses Observation } \\
\text { Scale } \\
\text { Clinical Global } \\
\text { Impression } \\
\text { depression }\end{array}$ & $\begin{array}{l}\text { SAE reported sig. more in placebo } \\
\text { than treatment group (AE: RR } \\
1.29, \text { CI } 1.03-1.61 \text {; SAE: RR } 1.58, \\
\text { CI } 1.03-2.42 \text { ) in particular } \\
\text { cardiovascular and } \\
\text { cerebrovascular events - } 9 \text { in } \\
\text { treatment group vs } 28 \text { in placebo } \\
\text { group); no sig. effects blood } \\
\text { pressure levels. }\end{array}$ \\
\hline \multirow[t]{4}{*}{ Falls } & $\begin{array}{l}\text { Allan \& al. } \\
(2009) \\
{[23]}\end{array}$ & $\begin{array}{l}\text { What are the } \\
\text { modifiable risk } \\
\text { factors for falls in } \\
\text { people with } \\
\text { dementia? }\end{array}$ & $\begin{array}{l}\text { Prospective } \\
\text { cohort study } \\
(12 \text { mths) }\end{array}$ & $\begin{array}{l}\text { Total } n=179, \\
\text { Controls } n=39, A D n=38 \text {, } \\
\text { VD } n=32, D L B n=30, \\
\text { PDD } n=40\end{array}$ & $\begin{array}{l}\text { Medical history, } \\
\text { CAMCOG, physical } \\
\text { activity scale, BMI, } \\
\text { mobility, PD rating } \\
\text { scale, ADL, } \\
\text { depression, } \\
\text { behavioural } \\
\text { symptoms, } \\
\text { autonomic } \\
\text { assessment }(\mathrm{OH}), \\
\text { falls }\end{array}$ & $\begin{array}{l}\text { Cardiovascular medication only: } \\
\text { sig. predictor in univariate analysis } \\
\text { for all dementia (HR } 2.08 ; \text { CI } \\
1.15-3.75 \text { ) and when stratified per } \\
\text { diagnosis (HR } 1.91 ; \text { CI } 1.03- \\
\text { 3.54); Trend sig. in multivariate } \\
\text { analysis when stratified by } \\
\text { diagnosis (HR } 1.98 ; \text { CI } 0.994- \\
3.96 \text { ) }\end{array}$ \\
\hline & $\begin{array}{l}\text { Asada \& al. } \\
(1996) \\
{[24]}\end{array}$ & $\begin{array}{l}\text { What are the } \\
\text { predictors of fall- } \\
\text { related injuries in } \\
\text { people with } \\
\text { dementia? }\end{array}$ & $\begin{array}{l}\text { Prospective } \\
\text { cohort study } \\
\text { (12 mths) }\end{array}$ & $\begin{array}{l}\text { Total } n=184 \\
98 \text { controls, } 86 \text { people } \\
\text { with dementia }\end{array}$ & $\begin{array}{l}\text { Cognition, } \\
\text { behavioural } \\
\text { problems, ADL, } \\
\text { medication, history } \\
\text { of falls, visual \& } \\
\text { hearing acuity, falls }\end{array}$ & $\begin{array}{l}\text { Cardiovascular medication only: } \\
\text { non significant contributor to falls- } \\
\text { related injuries (OR 0.9; CI 0.6- } \\
1.5 \text { ) }\end{array}$ \\
\hline & $\begin{array}{l}\text { Eriksson, \& } \\
\text { al., } 2007 \\
\text { [20] (incl. } \\
\text { erratum } \\
{[21] \text { ) }}\end{array}$ & $\begin{array}{l}\text { What are the risk } \\
\text { factors for falls in } \\
\text { people with and } \\
\text { without dementia? }\end{array}$ & $\begin{array}{l}\text { Prospective } \\
\text { cohort study } \\
(6 \text { mths })\end{array}$ & $\begin{array}{l}\text { Total } n=186 \\
83 \text { without dementia; } \\
103 \text { with dementia }\end{array}$ & $\begin{array}{l}\text { Cognition, vision, } \\
\text { hearing, walking } \\
\text { ability, ADL, } \\
\text { medication, falls }\end{array}$ & $\begin{array}{l}\text { In Erratum: In people with } \\
\text { dementia in univariate analysis, } \\
\text { taking diuretics was a significant } \\
\text { risk factor (IRR } 1.86 \text {; CI } 1.07- \\
3.23 \text { ). Not significant in } \\
\text { multivariate analysis. }\end{array}$ \\
\hline & $\begin{array}{l}\text { Pellfolk \& } \\
\text { Gustafsson } \\
(2009) \\
{[22]}\end{array}$ & $\begin{array}{l}\text { What are the risk } \\
\text { factors for falls in } \\
\text { people with } \\
\text { dementia? }\end{array}$ & $\begin{array}{l}\text { Prospective } \\
\text { study cohort } \\
(6 \text { mths })\end{array}$ & $\begin{array}{l}\text { Total } n=160 \text { people } \\
\text { with dementia; of those } \\
n=64 \text { fallers and } n=96 \\
\text { non fallers }\end{array}$ & $\begin{array}{l}\text { Cognition, vision, } \\
\text { hearing, ADL, } \\
\text { behavioural and } \\
\text { psychiatric } \\
\text { symptoms, use of } \\
\text { medication, falls }\end{array}$ & $\begin{array}{l}\text { No sig. difference in AHT (beta- } \\
\text { blockers, CCB, ACE inhibitors, } \\
\text { diuretics) between fallers and non- } \\
\text { fallers. No effect sizes reported. }\end{array}$ \\
\hline
\end{tabular}




\begin{tabular}{|c|c|c|c|c|c|c|}
\hline \multirow[t]{5}{*}{$\begin{array}{l}\text { Behavioural } \\
\text { problems }\end{array}$} & $\begin{array}{l}\text { Herrmann } \\
\text { \& al. } \\
(2004) \\
{[25]}\end{array}$ & $\begin{array}{l}\text { What is the } \\
\text { relation between } \\
\text { aggression and } B B \\
\text { use in } A D \text { patients? }\end{array}$ & $\begin{array}{l}\text { RCT (cross- } \\
\text { over design); } \\
\text { total duration } \\
15 \text { wks }\end{array}$ & Total $n=11$ & $\begin{array}{l}\text { Aggression } \\
\text { (retrospective Overt } \\
\text { Aggression Scale), } \\
\text { MMSE, Depression, }\end{array}$ & $\begin{array}{l}\text { Sig. decrease in verbal aggression } \\
\text { in treatment group but not in total } \\
\text { aggression score; higher baseline } \\
\text { aggression, higher MMSE and } \\
\text { lower growth hormone response to } \\
\text { clonidine challenge predicted } \\
\text { improvement in aggression. No } \\
\text { effect size reported. }\end{array}$ \\
\hline & $\begin{array}{l}\text { Peskind, } \\
\text { Tsuang \& } \\
\text { Bonner } \\
(2005) \\
{[26]}\end{array}$ & $\begin{array}{l}\text { Does propranolol } \\
\text { (BB) reduce } \\
\text { disruptive } \\
\text { behaviour? }\end{array}$ & RCT (6wks) & $\begin{array}{l}\text { Total } n=31 \text { with } \\
\text { probable or possible AD; } \\
n=17 \text { on } B B, n=14 \\
\text { placebo }\end{array}$ & $\begin{array}{l}\text { NPI change, } \\
\text { Clinical Global } \\
\text { Impression of } \\
\text { Change }\end{array}$ & $\begin{array}{l}\text { Overall score of NPI but no } \\
\text { individual sub-score sig. } \\
\text { improved in treatment group } \\
\text { compared to placebo group. } \\
\text { However, within treatment } \\
\text { group, results showed sig. } \\
\text { reductions in agitation/ } \\
\text { aggression scores and anxiety } \\
\text { scores from baseline to follow- } \\
\text { up. No effect size reported. }\end{array}$ \\
\hline & $\begin{array}{l}\text { Shankle, } \\
\text { Nielson, \& } \\
\text { Cotman, } \\
(1995) \\
{[28]}\end{array}$ & $\begin{array}{l}\text { Does low-dose } \\
\text { propranolol (BB) } \\
\text { reduce aggression } \\
\text { and agitation in } \\
\text { people with } \\
\text { dementia? }\end{array}$ & $\begin{array}{l}\text { Case series, } \\
\text { mean follow- } \\
\text { up } 6 \text { mths }\end{array}$ & Total $n=12$ & $\begin{array}{l}\text { Aggression (by } \\
\text { proxy; caregiver } \\
\text { rating, CMAI, CBQ), } \\
\text { propranolol given } \\
\text { until aggression } \\
\text { stopped }\end{array}$ & $\begin{array}{l}\text { Sig. improvement compared to } \\
\text { pre-treatment aggression levels } \\
\text { (proxy rating); CMAI showed sig. } \\
\text { reduction in physical and verbal } \\
\text { aggression and wandering in } \\
\text { responders }(n=8) \text { only. CBQ } \\
\text { showed sig improvements in all } \\
\text { subscales for resp. and non-resp. } \\
\text { except wandering; lower MMSE } \\
\text { correlated with treatment efficacy. } \\
\text { No effect size reported. }\end{array}$ \\
\hline & $\begin{array}{l}\text { Wang \& al. } \\
(2009) \\
{[27]}\end{array}$ & $\begin{array}{l}\text { How effective and } \\
\text { tolerable is } \\
\text { prazosin (alpha } \\
\text { adrenergic blocker) } \\
\text { for behavioural } \\
\text { symptoms in AD } \\
\text { patients? }\end{array}$ & $\begin{array}{l}\text { Double-blind } \\
\text { RCT; duration } \\
8 \text { wks }\end{array}$ & $\begin{array}{l}\text { Total } n=24(n=11 \text { in } \\
\text { treatment group; } n=11 \\
\text { in control group at } \\
\text { baseline, } n=7 \text { in } \\
\text { treatment group and } n=6 \\
\text { in placebo group at } \\
\text { follow up) }\end{array}$ & $\begin{array}{l}\text { Clinical Global } \\
\text { Impression of } \\
\text { Change and change } \\
\text { from baseline in NPI } \\
\text { and BPRS; side } \\
\text { effects, changes in } \\
\text { BP, functional status }\end{array}$ & $\begin{array}{l}\text { Sig. improvement in all } \\
\text { behavioural outcome measures in } \\
\text { treatment group compared to } \\
\text { placebo. Similar side effects, BP } \\
\text { levels and functional status. No } \\
\text { effect size reported. }\end{array}$ \\
\hline & $\begin{array}{l}\text { Weiler, } \\
\text { Mungas \& } \\
\text { Bernick }\end{array}$ & $\begin{array}{l}\text { Does propanolol } \\
\text { (BB) improve } \\
\text { disruptive }\end{array}$ & 6 case studies & $\mathrm{N}=6$ with dementia & $\begin{array}{l}\text { By-proxy } \\
\text { observations }\end{array}$ & $\begin{array}{l}\text { Improvements in behaviour } \\
\text { observed }\end{array}$ \\
\hline
\end{tabular}




\begin{tabular}{|c|c|c|c|c|c|c|}
\hline & $\begin{array}{l}(1988) \\
{[29]}\end{array}$ & behaviour? & & & & \\
\hline \multirow[t]{2}{*}{ Depression } & $\begin{array}{l}\text { Ban \& al. } \\
(1990) \\
{[34]}\end{array}$ & $\begin{array}{l}\text { What effects has } \\
\text { nimodipine (CCB) } \\
\text { in dementia } \\
\text { treatment? }\end{array}$ & RCT & $\begin{array}{l}\mathrm{N}=178 \text { with dementia, } \\
\mathrm{n}=89 \text { treatment }(\mathrm{CCB}) ; \\
\mathrm{n}=89 \text { control }\end{array}$ & depression & $\begin{array}{l}\text { Sig. more improvement regarding } \\
\text { depression in treatment than } \\
\text { placebo group. No effect size } \\
\text { reported. }\end{array}$ \\
\hline & $\begin{array}{l}\text { Newman } \\
(1999) \\
{[35]}\end{array}$ & $\begin{array}{l}\text { What is the } \\
\text { relationship of AD } \\
\text { and VaD to } \\
\text { depression? }\end{array}$ & Cohort study & $\begin{array}{l}\mathrm{n}=2341, \mathrm{n}=749 \mathrm{AD} ; \\
\mathrm{n}=208 \text { VaD; } \mathrm{n}=175 \text { other } \\
\text { dementia; of total } \mathrm{n}= \\
29 \text { diagnosed with } \\
\text { depression }\end{array}$ & $\begin{array}{l}\text { MMSE; cognitive and } \\
\text { physical } \\
\text { assessments, } \\
\text { depression, BB use }\end{array}$ & $\begin{array}{l}\text { BB use was not a sig. covariate in } \\
\text { the relationship between dementia } \\
\text { and depression (OR not reported) }\end{array}$ \\
\hline \multirow[t]{2}{*}{$\begin{array}{l}\text { Sleep } \\
\text { problems, } \\
\text { pain, kidney } \\
\text { problems, } \\
\text { incontinence }\end{array}$} & $\begin{array}{l}\text { Suzuki, } \\
\text { Meguro \& } \\
\text { Meguro } \\
(2011) \\
{[39]}\end{array}$ & $\begin{array}{l}\text { Is there an } \\
\text { association } \\
\text { between sleep } \\
\text { disturbance, } \\
\text { decreased daily } \\
\text { activity and } \\
\text { impaired nocturnal } \\
\text { reduction in BP in } \\
\text { people with } \\
\text { dementia? }\end{array}$ & $\begin{array}{l}\text { Prospective } \\
\text { cohort study } \\
\text { (14 days) }\end{array}$ & $\mathrm{N}=107$ with dementia & $\begin{array}{l}\text { ADL, ABPM, } \\
\text { evaluation of } \\
\text { sleep/wake pattern }\end{array}$ & $\begin{array}{l}\text { No sig. differences in use of AHT } \\
\text { between dippers and non-dippers } \\
\text { or low and high ADL (no effect } \\
\text { sizes reported) }\end{array}$ \\
\hline & $\begin{array}{l}\text { Ridgeway } \\
\text { \& al. } \\
(2008) \\
{[44]}\end{array}$ & $\begin{array}{l}\text { Which co- } \\
\text { morbidities and } \\
\text { medicines are } \\
\text { associated with } \\
\text { urinary and fecal } \\
\text { incontinence in a } \\
\text { long-term care } \\
\text { population? }\end{array}$ & $\begin{array}{l}\text { Retrospective } \\
\text { cohort study }\end{array}$ & $\mathrm{N}=67$ female residents & $\begin{array}{l}\text { Medications, co- } \\
\text { morbidities }\end{array}$ & $\begin{array}{l}\text { Dementia was associated with } \\
\text { urinary (OR } 4.3, \text { CI } 1.3-17.4 \text { ) and } \\
\text { fecal (OR } 6.8, \text { CI } 1.8-47.2 \text { ) } \\
\text { incontinence in a multivariate } \\
\text { analysis. AHT was not associated } \\
\text { with UI or FI (no effect sizes } \\
\text { reported). }\end{array}$ \\
\hline \multirow[t]{2}{*}{$\begin{array}{l}\text { Cholin- } \\
\text { esterase } \\
\text { inhibitors }\end{array}$} & $\begin{array}{l}\text { Grossberg } \\
\& \text { al. } \\
(2000) \\
{[46]}\end{array}$ & $\begin{array}{l}\text { Are there any } \\
\text { adverse pharmaco- } \\
\text { dynamic drug } \\
\text { interactions with } \\
\text { rivastigmine and } \\
\text { other classes of } \\
\text { medications? }\end{array}$ & $\begin{array}{l}\text { Prospective } \\
\text { cohort study } \\
\text { over } 6 \text { mnths }\end{array}$ & $\begin{array}{l}\mathrm{N}=2459 ; \mathrm{n}=1696 \text { using } \\
\text { rivastigmine; } \mathrm{n}=763 \\
\text { controls }\end{array}$ & $\begin{array}{l}22 \text { types of adverse } \\
\text { events }\end{array}$ & $\begin{array}{l}\text { No significant pattern of increase } \\
\text { in AEs was found for users of AHT } \\
\text { as one group and beta blockers as } \\
\text { well as alpha blockers as individual } \\
\text { medication types. However, for } \\
\text { diuretics, a significant difference } \\
\text { was found between people with } \\
\text { and without rivastigmine. }\end{array}$ \\
\hline & $\begin{array}{l}\text { Pariente \& } \\
\text { al. }(2010) \\
{[47]}\end{array}$ & $\begin{array}{l}\text { What are factors } \\
\text { associated with } \\
\text { serious adverse }\end{array}$ & $\begin{array}{l}\text { Population } \\
\text { study based } \\
\text { on the French }\end{array}$ & $\begin{array}{l}773 \text { reports about } \\
\text { cholinesterase inhibitors } \\
\text { mentioning a total of }\end{array}$ & $\begin{array}{l}\text { ADRs leading to } \\
\text { death, } \\
\text { hospitalisation or }\end{array}$ & $\begin{array}{l}\text { Factors associated with serious } \\
\text { ADRs were age, use of atypical } \\
\text { antipsychotics, use of conventional }\end{array}$ \\
\hline
\end{tabular}




\begin{tabular}{|c|c|c|c|c|c|c|}
\hline & & $\begin{array}{l}\text { drug reactions in } \\
\text { patients treated } \\
\text { with cholinesterase } \\
\text { inhibitors? }\end{array}$ & $\begin{array}{l}\text { pharmaco- } \\
\text { vigilance } \\
\text { database from } \\
\text { drug } \\
\text { launching up } \\
\text { to } 2007\end{array}$ & 1044 ADRs & $\begin{array}{l}\text { prolongation of } \\
\text { hospitalisation }\end{array}$ & $\begin{array}{l}\text { antipsychotics and use of AHT (OR } \\
2.11, \text { CI } 1.47-3.02) ; \text { More patients } \\
\text { with serious ADRs ( } 33.8 \% \text { of all } \\
\text { patients) than non-serious ADRs } \\
\text { ( } 19.7 \% \text { of all patients) when using } \\
\text { AHT alongside cholinesterase } \\
\text { inhibitors. }\end{array}$ \\
\hline & $\begin{array}{l}\text { Rozzini \& } \\
\text { al. }(2005) \\
{[45]}\end{array}$ & $\begin{array}{l}\text { What is the } \\
\text { relationship } \\
\text { between AHT and } \\
\text { cholinesterase } \\
\text { inhibitors? }\end{array}$ & $\begin{array}{l}\text { Prospective } \\
\text { cohort study; } \\
40 \text { wks }\end{array}$ & $\begin{array}{l}\mathrm{N}=416 ; \mathrm{n}=161 \mathrm{AHT} \\
\text { users; } \mathrm{n}=255 \text { not } \mathrm{AHT} \\
\text { users }\end{array}$ & MMSE, ADL, & $\begin{array}{l}\text { Sig difference between AHT user } \\
\text { and non-user in MMSE in favour of } \\
\text { users at wk } 16 \text { (T2). No sig. } \\
\text { difference at T3 ( } 40 \text { wks). Sig. } \\
\text { higher MMSE for users in those that } \\
\text { respond to cholinesterase } \\
\text { inhibitors, but not in non- } \\
\text { responders. No effect sizes } \\
\text { reported. }\end{array}$ \\
\hline & $\begin{array}{l}\text { Tavassoli \& } \\
\text { al. (2007) } \\
{[48]}\end{array}$ & $\begin{array}{l}\text { What are the drug } \\
\text { interactions with } \\
\text { cholinesterase } \\
\text { inhibitors? }\end{array}$ & $\begin{array}{l}\text { Analysis of } \\
\text { spontaneous } \\
\text { reports } \\
\text { regarding } \\
\text { cholin- } \\
\text { esterase } \\
\text { inhibitors } \\
\end{array}$ & $\begin{array}{l}\mathrm{N}=1058 \text { spontaneous } \\
\text { reports incl } \\
\text { cholinesterase inhibitors }\end{array}$ & $\begin{array}{l}\text { Beta blockers, } \\
\text { Calcium channel } \\
\text { antagonists }\end{array}$ & $\begin{array}{l}\text { Beta blockers were among the } \\
\text { most frequently encountered } \\
\text { drugs involved in DDI ( } 83 \text { cases) } \\
\text { with cholinesterase inhibitors }\end{array}$ \\
\hline \multirow[t]{2}{*}{ Polypharmacy } & $\begin{array}{l}\text { Giron \& al. } \\
(2001) \\
{[50]}\end{array}$ & $\begin{array}{l}\text { What is the extent } \\
\text { of inappropriate } \\
\text { drug use in people } \\
\text { with and without } \\
\text { dementia? }\end{array}$ & $\begin{array}{l}\text { Prospective } \\
\text { cohort study } \\
(8-10 \text { yrs })\end{array}$ & $\begin{array}{l}\mathrm{N}=681 ; \mathrm{n}=188 \text { with } \\
\text { dementia; } \mathrm{n}=493 \\
\text { without dementia }\end{array}$ & $\begin{array}{l}\text { Drug groups; drug } \\
\text { duplications }\end{array}$ & $\begin{array}{l}\text { People with dementia were sig. } \\
\text { more likely to use high-ceiling } \\
\text { diuretics and sig. less likely to use } \\
\text { BBs and CCBs than people without } \\
\text { dementia; } \\
\text { no differences in drug duplication } \\
\text { between people with and without } \\
\text { dementia (no effect sizes } \\
\text { reported). }\end{array}$ \\
\hline & $\begin{array}{l}\text { Montastruc } \\
\& \text { al. } \\
(2013) \\
{[51]}\end{array}$ & $\begin{array}{l}\text { What is the } \\
\text { prevalence of } \\
\text { potentially } \\
\text { inappropriate } \\
\text { medication use in } \\
\text { people with mild to } \\
\text { moderate AD? }\end{array}$ & $\begin{array}{l}\text { Prospective } \\
\text { cohort study } \\
(4 \text { yrs) }\end{array}$ & $\mathrm{N}=684$ with $\mathrm{AD}$ & $\begin{array}{l}\text { ADL, MMSE, NPI, } \\
\text { PIM use }\end{array}$ & $\begin{array}{l}3.1 \% \text { of sample used } \\
\text { inappropriate centrally acting } \mathrm{AHT} \text {; } \\
2.9 \% \text { of sample used } \\
\text { inappropriate short acting calcium } \\
\text { channel inhibitors. }\end{array}$ \\
\hline Orthostatic & Anderson \& & Is orthostatic & Cross- & $A D n=235$ & MMSE, medication, & $\mathrm{OH}$ occurred sig. more in DLB than \\
\hline
\end{tabular}




\begin{tabular}{|c|c|c|c|c|c|c|}
\hline \multirow[t]{2}{*}{ Hypotension } & $\begin{array}{l}\text { al. (2008) } \\
\text { [54] }\end{array}$ & $\begin{array}{l}\text { hypotension more } \\
\text { common in people } \\
\text { with dementia than } \\
\text { in those without } \\
\text { cognitive } \\
\text { impairment? }\end{array}$ & $\begin{array}{l}\text { sectional } \\
\text { cohort study }\end{array}$ & $\begin{array}{l}\text { DLB } n=52 ; \text { controls } n= \\
62\end{array}$ & $\begin{array}{l}\text { after resting in } \\
\text { supine position: } \\
\text { immediately and } \\
\text { after } 1,3,5,10 \text { mins } \\
\text { of standing }\end{array}$ & $\begin{array}{l}\text { in } A D \text {, and in } A D \text { sig. more than in } \\
\text { controls. } \\
\text { No sig. difference in } A H T \text { between } \\
\text { groups. No effect sizes reported. }\end{array}$ \\
\hline & $\begin{array}{l}\text { Mehrabian } \\
\& \text { al. } \\
(2010) \\
{[55]}\end{array}$ & $\begin{array}{l}\text { What is the } \\
\text { relationship } \\
\text { between } \\
\text { orthostatic } \\
\text { hypotension }(\mathrm{OH}) \\
\text { and cognition in } \\
\text { people with } \\
\text { cognitive } \\
\text { impairment? }\end{array}$ & Cohort study & $\begin{array}{l}\text { Total total } n=495 \\
\text { consecutive patients with } \\
\text { memory complaints } \\
\text { visiting a memory clinic }\end{array}$ & $\begin{array}{l}\text { Sitting and standing } \\
\text { (after } 1 \text { and } 3 \text { min) } \\
\text { BP. }\end{array}$ & $\begin{array}{l}\text { Patients with } \mathrm{OH} \text { used a sig. } \\
\text { higher number of AHT than those } \\
\text { without } \mathrm{OH} \text {. OH patients had sig. } \\
\text { poorer cognitive function. This was } \\
\text { independent of AHT. OH was } \\
\text { significantly more often present in } \\
\text { VaD, AD, MCI than in cognitively } \\
\text { non-impaired individuals in an } \\
\text { overall test (no individual } \\
\text { differences or effect sizes } \\
\text { reported). }\end{array}$ \\
\hline
\end{tabular}

* $\mathrm{CI}$ refers to a $95 \%$ Confidence Interval; $\mathrm{ABPM}=$ ambulatory blood pressure monitoring; $\mathrm{ACE}-\mathrm{I}=\mathrm{ACE}$ inhibitor; $\mathrm{AD}=\mathrm{Alzheimer}$ 's disease; $\mathrm{ADL}=\mathrm{activities}$ of daily living; $\mathrm{ADR}=$ adverse drug reaction; $\mathrm{AHT}=$ antihypertensive treatment; $\mathrm{ARB}=$ angiotensin receptor blocker; $\mathrm{BB}=$ beta blockers; $\mathrm{BP}=$ blood pressure; $\mathrm{BPRS}=\mathrm{Brief}$ Psychiatric Rating Scale; CAMCOG = Cambridge Cognition computerized cognitive test battery; $C B Q=$ California Behavior Questionnaire; CDR = Clinical Dementia Rating; CCB = calcium channel blocker; CMAI = Cohen Mansfield Agitation Inventory; DDI = drug-drug interaction; DLB = dementia with Lewy bodies; FI = fecal incontinence; GFR = glomerular filtration rate; $\mathrm{HR}=$ hazard ratio; IRR = incidence rate ratio; $\mathrm{MCI}=$ mild cognitive impairment; $\mathrm{MMSE}=$ Mini Mental State Examination; $\mathrm{mths}=$ months; $\mathrm{NPI}=$ Neuropsychiatric Inventory; $\mathrm{OH}=$ orthostatic hypotension; $\mathrm{OR}=$ odds ratio; PDD = Parkinson's disease dementia; PIM = potentially inappropriate medication; RCT = randomised controlled trial; SAE = serious adverse event; UI = urinary incontinence; VaD = vascular dementia; wks = weeks 


\section{Discussion}

The first phase of this review identified several important domains of outcome relevant to the treatment of hypertension in people with dementia - not only cardio-vascular events but also falls, fractures and syncope, depression, orthostatic hypotension, behavioural disturbances, polypharmacy risks, kidney problems, incontinence, sleep problems, interactions with cholinesterase inhibitors and pain could also be affected. The second phase examined each of these areas in turn and concluded that relatively little is known about the effect of antihypertensive therapy upon these outcomes in people with dementia (as opposed to older people in general). From what we found, calcium channel blockers might have a beneficial additional effect upon depression, beta-blockers may reduce behaviour disturbance, ACE inhibitors might increase the risk of mortality, and there was no consistent evidence of any relationship between antihypertensive therapy and falls, orthostatic hypotension or interactions with cholinesterase inhibitors. Overall, relatively few studies of antihypertensive therapy have been undertaken in people with dementia, and there is virtually no information specific to different dementia sub-types.

This review could be subject to a publication bias towards positive outcomes and benefits, and against the reporting of adverse consequences of treatment, which means that the possible benefits the review identified of antihypertensive treatment should be interpreted with caution.

This review adds to the little that is known specifically about the treatment of hypertension in people with dementia. Previous reviews have proposed but not proven that such treatment might delay the onset of dementia ${ }^{8-9}$. Another review concluded that there is no convincing evidence of the effectiveness of antihypertensive therapy in the reduction of cardiovascular and cerebrovascular events in people with dementia ${ }^{56}$, which our review has confirmed. This review, however, illustrates the range of potential harms and benefits of antihypertensive therapy in people with dementia beyond those mentioned in most trials of antihypertensive agents - although it found little firm evidence about them. 
Given the lack of firm evidence of increased adverse outcomes arising from antihypertensive therapy in people with dementia, there is currently no reason to produce materially different guidelines for the treatment of hypertension in people with dementia, and justifies the current presumption that the favourable evidence drawn from the treatment of non-demented people should be extrapolated to those with dementia. As part of this guidance, the side effects of antihypertensive drugs should be sought on a routine basis: those looking after hypertension in people with dementia may need to gather a collateral history to do so adequately. Our review does not contradict guidance about prescribing in general in frailty states, which would apply to many people in the later stages of dementia: this includes withdrawing preventative medication in those believed to be in their last months of life when the potential benefits diminish in magnitude, and confirming whether the consent to treatment made by patients before the onset of dementia is still valid when they have lost mental capacity $^{57}$. Our review also should not discourage physicians caring for acutely ill people with dementia from withdrawing antihypertensive drugs temporarily while they hare cardiovascular instability or are at high risk of problems such as acute kidney injury.

Nevertheless, the lack of evidence of harm or benefit in this group means that there is at least a concern about the safety of antihypertensive treatment and a gap in the evidence base. Given the growing numbers of people with dementia and hence with dementia and hypertension, and growing concerns over both polypharmacy and frailty, we propose that clinicians should audit carefully their treatment of hypertension in this group of patients, trials of safe withdrawal of antihypertensive

therapy should be considered for this population (as have been done for the general population) ${ }^{58-59}$ taking the wide range of outcomes identified in this review into account, and more work is required to clarify the factors that should determine when antihypertensive therapy should be withdrawn in the later stages of the dementia process.

\section{References}

1. World Health Organization. Dementia: a public health priority. 2012. http://apps.who.int/iris/bitstream/10665/75263/1/9789241564458 eng.pdf?ua=1. Accessed on January 20, 2014. 
2. Chow, C. K., Teo, T.T., Rangarajan, S., Islam, S., et al. Prevalence, awareness, treatment, and control of hypertension in rural and urban communities in high-, middle-, and low-income countries. JAMA 2013; 310(9): 959-968.

3. Meade, T. W., Peart, S., Brennan, P. J., Broughton, P., et al. Medicinal Research Council trial of treatment of hypertension in older adults - principal results. British Medical Journal 1992; 304: 405-412.

4. Probstfield, J. L. Prevention of stroke by antihypertensive drug-treatment in older persons with isolated hypertension - final results of the Systolic Hypertension in the Elderly Program (SHEP). Jama-Journal of the American Medical Association, 1991; 265: 3255-3264.

5. Insua, J. T., Sacks, H. S., Lau, T. S., Lau, J. et al. Drug treatment of hypertension in the elderly - a metaanalysis. Annals of Internal Medicine 1994; 121: 355-362.

6. Welsh, T.J., Gordon, A. \& Gladman, J., The treatment of hypertension in care home residents: A systematic review of observational studies. Journal of the American Medical Directors Association, 2013; doi:pii: S1525-8610(13)00383-6. 10.1016/j.jamda.2013.06.012. [Epub ahead of print] Accessed on January 20, 2014.

7. Grant, M.J. \& Booth, A. A typology of reviews: an analysis of 14 review types and associated methodologies. Health Information and libraries journal 2009; 26(2): 91-108.

8. Shah, K., Qureshi, S. U., Johnson, M., Parikh, N. et al. Does Use of Antihypertensive Drugs Affect the Incidence or Progression of Dementia? A Systematic Review. American Journal of Geriatric Pharmacotherapy 2009; 7: 250-261.

9. Wilson, D., Peters, R., Ritchie, K. \& Ritchie, C. W. 2011. Latest Advances on Interventions that May Prevent, Delay or Ameliorate Dementia. Ther Adv Chronic Dis, 2, 161-73.

10. Kehoe, P. G., Davies, N. M., Martin, R. M. \& Ben-Shlomo, Y. Associations of Angiotensin Targeting Antihypertensive Drugs with Mortality and Hospitalization in Primary Care Patients with Dementia. Journal of Alzheimers Disease 2013; 33: 999-1008.

11. Pantoni, L., Bianchi, C., Beneke, M., Inzitari, D. et al. The Scandinavian Multi-Infarct Dementia Trial: a double-blind, placebo-controlled trial on nimodipine in multi-infarct dementia. J Neurol Sci, 2000; 175: 116-23.

12. Pantoni, L., Del Ser, T., Soglian, A.G. Amigoni, S. et al. Efficacy and safety of nimodipine in subcortical vascular dementia: a randomized placebo-controlled trial. Stroke 2005; 36: 61924.

13. Pantoni, L., Rossi, R., Inzitari, D. Bianchi, C. et al. Efficacy and safety of nimodipine in subcortical vascular dementia: a subgroup analysis of the Scandinavian Multi-Infarct Dementia Trial. J Neurol Sci 2000; 175: 124-34.

14. Kennelly, S. P., Abdullah, L., Paris, D., Parish, J. et al. Demonstration of safety in Alzheimer's patients for intervention with an anti-hypertensive drug Nilvadipine: results from a 6-week open label study. Int J Geriatr Psychiatry 2011; 26: 1038-45.

15. Shaw, F. E. Falls in older people with dementia. Canada: Geriatrics and Aging 2003. http://ga.geriatricsandaging.ca/files/content/2003/August/0607dementiafall.pdf. Accessed on January 21, 2014.

16. Sourdet, S., Van Kan, G. A., Soto, M. E., Houles, M. et al. Prognosis of an Abnormal One-Leg Balance in Community-Dwelling Patients With Alzheimer's Disease: A 2-Year Prospective Study in 686 Patients of the REAL.FR Study. Journal of the American Medical Directors Association 2012; 13.

17. Van Doorn, C., Gruber-Baldini, A. L., Zimmerman, S., Hebel, J. R. et al. Dementia as a risk factor for falls and fall injuries among nursing home residents. Journal of the American Geriatrics Society 2003; 51: 1213-1218.

18. Gribbin, J., Hubbard, R., Gladman, J., Smith, C. et al. Risk of falls associated with antihypertensive medication: self-controlled case series. Pharmacoepidemiol Drug Saf 2011; 20: 879-84. 
19. Woolcott, J. C., Richardson, K. J., Wiens, M. O., Patel, B. et al. Meta-analysis of the Impact of 9 Medication Classes on Falls in Elderly Persons. Archives of Internal Medicine 2009; 169: 1952-1960.

20. Eriksson, S., Gustafson, Y. \& Lundin-Olsson, L. Characteristics associated with falls in patients with dementia in a psychogeriatric ward. Aging Clinical and Experimental Research 2007; 19: 97-103.

21. Eriksson, S., Gustafson, Y. \& Lundin-Olsson, L. Characteristics associated with falls in patients with dementia in a psychogeriatric ward (vol 19, pg 97, 2007). Aging Clinical and Experimental Research 2007; 19: 509.

22. Pellfolk, T., Gustafsson, T., Gustafson, Y. \& Karlsson, S. Risk factors for falls among residents with dementia living in group dwellings. International Psychogeriatrics 2009; 21: 187-194.

23. Allan, L. M., Ballard, C. G., Rowan, E. N. \& Kenny, R. A. Incidence and prediction of falls in dementia: a prospective study in older people. PLoS One 2009. http://onlinelibrary.wiley.com/o/cochrane/clcentral/articles/001/CN-00698001/frame.html. Accessed on January 21, 2014

24. Asada, T., Kariya, T., Kinoshita, T., Asaka, A. et al. Predictors of fall-related injuries among community-dwelling elderly people with dementia. Age and Ageing 1996; 25: 22-28.

25. Herrmann, N., Lanctôt, K. L., Eryavec, G. \& Khan, L. R. Noradrenergic activity is associated with response to pindolol in aggressive Alzheimer's disease patients. J Psychopharmacol 2004; 18: 215-20.

26. Peskind, E. R., Tsuang, D. W., Bonner, L. T., Pascualy, M. et al. Propranolol for disruptive behaviors in nursing home residents with probable or possible Alzheimer disease: a placebocontrolled study. Alzheimer Dis Assoc Disord 2005; 19: 23-8.

27. Wang, L. Y., Shofer, J. B., Rohde, K., Hart, K. L. et al. Prazosin for the Treatment of Behavioral Symptoms in Patients With Alzheimer Disease With Agitation and Aggression. American Journal of Geriatric Psychiatry 2009; 17: 744-751.

28. Shankle, W. R., Nielson, K. A. \& Cotman, C. W. Low-dose propranolol reduces aggression and agitation resembling that associated with orbitofrontal dysfunction in elderly demented patients. Alzheimer Dis Assoc Disord 1995; 9: 233-7.

29. Weiler, P. G., Mungas, D. \& Bernick, C. Propranolol for the control of disruptive behavior in senile dementia. J Geriatr Psychiatry Neurol 1988; 1: 226-30.

30. Wright, J. M. \& Musini, V. M. First-line drugs for hypertension. Cochrane Database Syst Rev, 2009; CD001841.

31. Wiysonge, C.S., U., Bradley H. A., Mayosi B. M., Maroney, R., T. et al. Beta-blockers for hypertension. Cochrane Database of Systematic Reviews 2012;

http://onlinelibrary.wiley.com/doi/10.1002/14651858.CD002003.pub4/pdf/standard. Accessed on January 21, 2014.

32. Bradley, H. A., Wiysonge, C. S., Volmink, J. A., Mayosi, B. M. et al. How strong is the evidence for use of beta-blockers as first-line therapy for hypertension? Systematic review and metaanalysis. J Hypertens 2006; 24: 2131-41.

33. Luijendijk, H. J., Van Den Berg, J. F., Hofman, A., Tiemeier, H. et al. Beta-Blockers and the Risk of Incident Depression in the Elderly. Journal of Clinical Psychopharmacology 2011; 31: 4550.

34. Ban, T. A., Morey, L., Aguglia, E., Azzarelli, O. et al. Nimodipine in the treatment of old age dementias. Prog Neuropsychopharmacol Biol Psychiatry 1990; 14: 525-51.

35. Newman, S. C. The prevalence of depression in Alzheimer's disease and vascular dementia in a population sample. J Affect Disord 1999; 52: 169-76.

36. Bliwise, D. L. Sleep disorders in Alzheimer's disease and other dementias. Clin Cornerstone 2004; 6 Suppl 1A: S16-28.

37. Ownby, R. L., Peruyera, G., Acevedo, A., Loewenstein, D. et al. Subtypes of Sleep Problems in Patients with Alzheimer Disease. Am J Geriatr Psychiatry 2013; 
http://www.sciencedirect.com/science/article/pii/S1064748112000024. Accessed on January 21, 2014.

38. Ziegler, M. G., Milic, M. \& Sun, P. Antihypertensive therapy for patients with obstructive sleep apnea. Curr Opin Nephrol Hypertens 2011; 20: 50-5.

39. Suzuki, R., Meguro, M. \& Meguro, K. Sleep disturbance is associated with decreased daily activity and impaired nocturnal reduction of blood pressure in dementia patients. Archives of Gerontology and Geriatrics 2011; 53: 323-327.

40. Graham, J. E., Robles, T. F., Kiecolt-Glaser, J. K., Malarkey, W. B. et al. Hostility and pain are related to inflammation in older adults. Brain, Behavior, and Immunity 2006; 20 (4): 389-400.

41. Guasti, L., Zanotta, D., Diolisi, A., Garganico, D. et al. Changes in pain perception during treatment with angiotensin converting enzyme-inhibitors and angiotensin II type 1 receptor blockade. Journal of Hypertension 2002; 20: 485-491.

42. Bolbrinker, J., Schedensack, G., Kolzsch, M., Breckwoldt, J. et al. Anti hypertensive treatment and renal function in geriatric emergency patients. Deutsche Medizinische Wochenschrift 2009; 134: 802-806.

43. Ruby, C. M., Hanlon, J. T., Boudreau, R. M., Newman, A. B. et al. The effect of medication use on urinary incontinence in community-dwelling elderly women. J Am Geriatr Soc 2010; 58: 1715-20.

44. Ridgeway, B., Chacko, L., Barber, M. D. \& Messinger-Rapport, B. J. Co-morbidities and incontinence in an elderly long-term care population. Journal of Pelvic Medicine and Surgery 2008; Conference, 29th Annual Scientific Meeting of the American Urogynecologic Society Chicago, IL United States.

45. Rozzini, L., Chilovi, B. V., Bellelli, G., Bertoletti, E. et al. Effects of cholinesterase inhibitors appear greater in patients on established antihypertensive therapy. International Journal of Geriatric Psychiatry 2005; 20: 547-551.

46. Grossberg, G. T., Stahelin, H. B., Messina, J. C., Anand, R. et al. Lack of adverse pharmacodynamic drug interactions with rivastigmine and twenty-two classes of medications. International Journal of Geriatric Psychiatry 2000; 15 (3): 242-247.

47. Pariente, A., Sanctussy, D. J. R., Miremont-Salame, G., Moore, N. et al. Factors associated with serious adverse reactions to cholinesterase inhibitors: A study of spontaneous reporting. CNS Drugs 2010; 24(1): 55-63.

48. Tavassoli, N., Sommet, A., Lapeyre-Mestre, M., Bagheri, H. et al. Drug interactions with cholinesterase inhibitors - An analysis of the French Pharmacovigilance Database and a comparison of two national drug formularies (Vidal, British National Formulary). Drug Safety 2007; 30: 1063-1071.

49. Model Of Care Polypharmacy Working Group. Polypharmacy Guidance. Scottish Government Health and Social Care Directorates (ed.) 2012; http://www.central.knowledge.scot.nhs.uk/upload/Polypharmacy\%20full\%20guidance\%20v 2.pdf. Accessed on January 20, 2014.

50. Giron, M. S., Wang, H. X., Bernsten, C., Thorslund, M. et al. The appropriateness of drug use in an older nondemented and demented population. J Am Geriatr Soc 2001; 49: 277-83.

51. Montastruc, F., Gardette, V., Cantet, C., Piau, A. et al. Potentially inappropriate medication use among patients with Alzheimer disease in real.fr: Be aware of atropinic and benzodiazepine drugs! Pharmacoepidemiology and Drug Safety 2013; Conference, 28th International Conference on Pharmacoepidemiology and Therapeutic Risk Management, ICPE 2012 Barcelona Spain.

52. Novak, V. \& Hajjar, I. The relationship between blood pressure and cognitive function. Nat Rev Cardiol 2010; 7: 686-98.

53. Perlmuter, L. C., Sarda, G., Casavant, V., O'Hara, K. et al. A review of orthostatic blood pressure regulation and its association with mood and cognition. Clin Auton Res 2012; 22: 99-107.

54. Andersson, M., Hansson, O., Minthon, L., Ballard, C. G. et al. The period of hypotension following orthostatic challenge is prolonged in dementia with Lewy bodies. Int J Geriatr Psychiatry 2008; 23: 192-8.

55. Mehrabian, S., Duron, E., Labouree, F., Rollot, F. et al. Relationship between orthostatic hypotension and cognitive impairment in the elderly. J Neurol Sci 2010; 299: 45-8. 
56. Beishon, L.C., Harrison, J.K., Harwood, R.H., Robinson, T.G. et al. The evidence for treating hypertension in older people with dementia: a systematic review. J Hum Hypertens. 2013; doi: 10.1038/jhh.2013.107. [Epub ahead of print]

57. Duerden, M., Avery, T. \& Payne, R. Polypharmacy and Medicines Optimisation - Making it safe and sound. London/UK: The King's Fund, 2013.

58. Iver, S., Naganathan, V., McLachlan, M.J. \& Le Couteur, D.G. Medication withdrawal trials in people aged 65 and older: a systematic review. Drugs Aging 2008; 25(12): 2021-1031.

59. Nelson, M., Reid, C., Krum, H. \& McNeil J. A systematic review of predictors of maintenance of normotension after withdrawal of antihypertensive drugs. American Journal of Hypertension 2001;14(2):98-105. 